\title{
The Religious Praxis of Women's Body, Sexuality and Domestication: The Discourse Analysis of Salafi Preaching Videos on Instagram
}

\author{
E Leiliyanti ${ }^{1}$, A Larasati ${ }^{2}$ \\ Language Education and Applied Linguistics Study Programs. Postgraduate School, Universitas \\ Negeri Jakarta ${ }^{1}$ \\ English Literature Study Program, Universitas Negeri Jakarta ${ }^{2}$ \\ \{eleiliyanti@unj.ac.id', amandalarasati100@.gmail.com²
}

\begin{abstract}
In today's digital era, religious preaching in social media, such as Instagram, can arguably be seen as no longer reflecting the up-to-the-minute platform of proselytization. However, such a medium provides a prompt and swift mode in delivering its messages to the addressers/receivers. This discourse analysis highlights the Salafi preaching videos (three one-minute-length videos) in Instagram, especially on how they propagate the issues of women's body and sexuality as well as domestication. It focuses on how these videos represent the catering of alternative Salafi strand of analysis on how the feminist Islamic discourse is devised and propagated. The data were taken from the one-minute-length of Salafi preaching videos based on stratified purposeful sampling. Deploying appraisal theory of language evaluation, its finding demonstrates that the language used by the Salafi preachers in their discourse demonstrates the plausible transcendental salvation of women vis-à-vis the way they interpret the religious praxis on women's body, sexuality and domestication.
\end{abstract}

Keywords: Salafi preaching videos on Instagram, women's body, sexuality and domestication, discourse analysis.

\section{Introduction}

In today's digital era, social media such as Instagram has a prominent role in the dissemination of $d a$ ' $w a$ or proselytization [1]. In the perspective of Arifuddin [2], the term $d a$ ' $w a$ can be defined as the act of propagating the messages of God to those who are referred as mad' $u$ or the recipient of the $d a$ ' $w a$ and imbue them to carry out positive deeds, benevolence, and virtues that are regarded to be compatible with the values of Islam. Thus by upholding such virtues and conducts, they can receive the blessings of God for their salvation and prosperity in worldly affairs and in the hereafter. The vast development of social media in spreading religious preaching through Instagram is also visible in Indonesia as a country that possesses enormous Muslim populations [2]. Various Muslim scholars in Indonesia have deployed social media including Instagram to promulgate the teachings and praxis of Islam. [3].

Instagram is deemed to be an effective media in propagating Islamic teachings messages since the platform allows religious scholars to convey their discernment about Islam through its sophisticated and interactive features such as photos and videos [1]. This makes users easily grasp the information propagated by the scholars through the audio and visual aspects rather than via elaborated descriptions [1]. One of the groups that has pivotal role in proselytizing Islam in Instagram is Salafism. Salafism is perceived as the group that is committed to restoring the pious teachings of Islam [1]. Underpinning the statement, Woodward, Umar, Rohmaniyah, \& Yahya [4] state that Salafi Muslims perceive the rituals and practices inscribed in the Sharia Law as 
compulsory. The uprightness of behavior also becomes the concern of Salafi scholars [4]. In conjunction to this, Nisa [1] expounds that the group is determined to applying the praxis of Islam in accordance with the teachings of the first Muslim generations, hence Salafi is renowned as a stringent Islamic movement. In alignment with this, Woodward, Umar, Rohmaniyah, \& Yahya [4] claim that Salafism is notoriously known for its exclusiveness, persistence in upholding the practices of Islam, and intolerance towards discrepancies. On Instagram, Salafi scholars create postings about puritan Islam that are aimed at bolstering people's understanding of the veracious principles of Islam by providing cogent sources to fortify the accuracy of their messages [1]. Such portrayal is enfolded in the three videos of Salafi Muslim scholars talking about how Muslim women (should?) perceive their own body, sexuality and domestication in relation with their mandatory of submitting to their husbands and complying with the husband's orders. In the Salafi preachers' videos, the scholars point out that their remarks are based on the reliable sources namely Islamic Law and the sayings of Prophet Muhammad SAW.

The transitivity system postulated by M.A.K.Halliday [5] and language of evaluation theory developed by Martin and White [6] were deployed to scrutinize the issues of women's body, sexuality and domestication on the three Salafi preachers' Instagram videos. It is organized by discussing the notions of women's body and sexuality and domestication, the research's methodology, the three selected videos analysis and conclusion.

\section{Women's Body, Sexuality and Domestication}

From the viewpoint of the patriarchal system, a woman's body is subjected to the logic of patriarchal culture - an obedient, docile entity that undergoes disciplining process or the object that cannot detach itself from the hegemonic relation of subject-object. The disciplining process occurs when women desire (or they are urged to look beautiful (read also: ideal)) to fulfil the patriarchal norms and standards. They are then busy covering themselves with the magical help of the cosmetic and clothing or voluntarily conducting plastic surgery or non-surgical treatment. They don themselves with fully-covered clothing or the clothes that can cover their physical imperfection or clothing that showcases the particular parts of their body. This praxis, that represents the mechanism of how women express their sexuality, operate not only in the public or private spheres, but also in the area where the segregation of these two spheres obscures, such as Instagram.

In Foucault's lens (1978), body becomes the medium that needs to be disciplined, not necessarily in form of repressive power, but rather in normalizing mode. This normalizing is important as the body speaks out the sexuality of its owner. In Islamic discourse women's body is closely correlated with the notion awrah, as previously discussed. The normalizing act in form of full donning of the women's body is not intended to cover the women's physical imperfection, but more to fortify themselves against the male gaze and other relevant (fe) male activities that put women as the object and/or position themselves as evil temptress. This implies that female beauty should only be consumed domestically by the husband, children or Mahrams. The urge of Muslim women to look enchanting at all times especially lies on the husband's pleasure. This, at the same time, indicates the male Muslim power exercise over their spouse's sexuality. Though need to look enchanting at all times, especially in front of their husbands, the women have the full authority in terms of household works and positive roles as "wives, mothers and ladies of the house", which place the husbands as the ones who nurture, respect them, as well as the ones whose permission is mandatory to the wives [7] .

\section{Method}

As previously stated, three videos of Salafi scholars' preaches relating to the issue of women's body, sexuality, and domestication were selected based on stratified purposeful sampling. The first video was taken from an Instagram account named @nasehat.pernikahan dated on May the $14^{\text {th }} 2019$ showcasing women's mandatory of serving their husbands first instead of their children. The second video was taken from the same account dated on May the $11^{\text {th }} 2019$ declaring women to stop checking their husbands' cellphones. The last one was taken from an Instagram 
account named @bukanustadz.id dated on August the $21^{\text {st }} 2019$ highlighting the ways to get to know one's significant other without having to be in a relationship with him or her. In investigating the issue of the religious praxis on women's body, sexuality, and domestication, the authors deployed the Transitivity framework developed by Halliday in scrutinizing the linguistic features by analyzing the types of processes used by the preachers in promulgating their messages. Meanwhile, Appraisal theory was employed to scrutinize the interpersonal aspect, i.e. the way the languages were deployed by the three Salafi preaches to evaluate the appropriateness and rectitude of the participants namely women and men, introducing other's propositions and voices to allow dialogic alternatives, and expressing emotions.

In the context of the Transitivity framework, language is deployed to delineate human experiences into a system of grammar comprising three elements namely participant, process, and circumstance [5]. In the lens of Halliday \& Matthiessen [5]., human experiences are classified into six types of processes namely material, mental, relational, behavioral, verbal, and existential. Material process is concerned with the process of performing an action, happening, and creating an entity [5]. Mental process showcases the internal aspect of humans, such as the act of perceiving, thinking, and sensing [5]. In addition, relational process is deployed to classify and identify entity [5]. Behavioral process represents the act that shows the mixture between physical action and psychological state [5]. Furthermore, Halliday \& Matthiessen [5] expounds that verbal process is concerned with the process of saying, explaining, commanding, criticizing, and calling. Meanwhile, in the perspective of Halliday \& Matthiessen [5], existential process is deployed to signify the existence and presence of an entity.

The following study was also complemented with Appraisal Framework developed by Martin \& White. Appraisal framework is an approach utilized to seek the way language expresses criticism, conveys emotions, showcases appreciation on phenomenon, and presents other voices in affirming or contending proposition, as well as gauges the intensity of phenomenon [6]. Martin \& White [6] elaborates the three domains of Appraisal Framework namely attitude, engagement, and graduation. Attitude deals with the expression of feelings, condemnation or applause on one's behavior, as well assessment on social phenomenon. Attitude is further classified into three sub-domains namely affect, judgement, and appreciation [8][6]. Engagement pertains to the inclusion of other's voices to affirm, consent, or contend one's proposition [6]. Meanwhile, in the perspective of Halliday \& Matthiessen [5], graduation is employed to gauge the intensity of phenomenon whether it is amplified or mitigated.

\section{Result and Discussion}

The first video showcases the responsibility of women to fulfill their husbands' call even though they need to take care of their children unless their husband will be infuriated. Three entities namely woman, man, and child are actors of the video. Meanwhile, the preacher, Ustad Khalid Basalamah serves as the narrator. Material and relational processes are the two most dominant process types employed by the cleric in delivering his preaching regarding the issue of domestication. From the total of 34 clauses, it is found that 9 clauses or $26.47 \%$ embody material process which could be seen from the deployment of verbs indicating the act of doing something such as "ganti", "tinggal", "masak". Material process was employed in the video to represent the acts committed by the woman namely the submissive acts that a woman is obliged to do in order to please her husband.

The use of material process to represent women's obligation in fulfilling their husbands' command is strengthened by the use of negative judgement of propriety which is mostly wrapped in imperative mood such as "tinggal", "matikan", "janganditambah". The negative judgement of propriety is employed by the scholar to appraise woman's behavior that must be in accordance with the value of Islam namely a woman should fulfill his husband's order unless man will be enraged. In this video, the Salafi scholar conceives that a woman must promptly serve her husband once he calls him unless her husband will be agitated. It is in alignment with the principle of Salafism that a woman must comply with her husband's order [7]. In this context, the Salafi scholar frames the husband as a "big baby" that must be served unless he will be furious. It is believed that by the Salafi people that a woman must not neglect her husband's order [9]. 
Subservience of wife to her husband is a arguably cardinal value in Salafism. Therefore, the obedience of woman is the key to achieve her husband's satisfaction and contentment. The Salafi scholar in this video claim that a woman is supposed to immediately respond to his husband's call even though she is in the middle of doing other activity including changing their child's diaper. Based on the utterance of the scholar, it can be inferred that in Salafism, a husband should be placed as the top's priority of a woman. In the lens of Salafi scholars, Muslim women must be able to cope with her two responsibilities namely as a wife and a mother figure who must be capable of executing her household duties. It is showcased in the video in which woman is told to prioritize her husband first despite having to sacrifice her child. It can be seen in the clause "nggak apa-apa anak kecil nangis" indicating that the cry of a baby is a trivial issue compared with the husband's. Instead, woman should serve her husband unless he will whimper and scream if his call is not responded by his wife.

The superiority of man in a family is also depicted by the portrayal of man as the person that must be given with top priority affection and attention by his wife. If they are not treated properly, they will burst into resentment. Albeit, most of the clauses employ judgement of propriety in the form of imperative mood to showcase the mandatory of woman of being submissive to her husband, there are 3 clauses indicating the patience and acceptance of man in waiting for his wife to respond to his call which functions to neutralize the framing of men's authority in the family which is manifested through the use of relational process and positive judgement "Tapi, kalo ada suami kaya gitu MashaAllah". However, in this video, men are generally constructed to be an impatient creature that must be paid on attention immediately. The negative judgement of propriety in the last clause namely "jangan ditambah jadi lebih buruk", showcases how woman is supposed to appease her husband for the goodness of herself and also her family.

The second video taken from the account@nasehat.pernihakan highlights Salafi scholar's view about the importance of woman to gain her husband's acceptance for her salvation The video vehemently showcases the dominance of man over his wife through the use of material process and negative judgement of propriety. In this context, material process constitutes most of the clauses with 14 clauses from 21 clauses or $66.7 \%$. The material process is employed by the Salafi scholar to showcase the act that a woman is supposed to do in order to acquire blessing and salvation such as "buang", "cek", "didik". It is further underpinned by the use of negative judgement of propriety to condemn the act that is committed by woman namely checking her husband's phone. The dominance of man in a family is constructed by the responsibility of husband to supervise her wife. It can be perceived that in the viewpoint of the scholar, woman must not interfere her husband's affairs and respect his privacy by not checking her husband's cellphone. It is exemplified by the material process "buang" as in the two clauses "suka ngecek handphone suami, buang" and the negative judgement of propriety in the form of declarative mood. On the contrary, it is her husband that is supposed take control on her. In the perspective of the scholar, the salvation of woman can only be attained if her husband is willing to approve the deeds that her wife performs. Such portrayal showcases the vulnerability and the powerlessness of woman who needs to appease her husband and be submissive to him, hence she can obtain blessings from God. It is actualized by the use of negative judgement of propriety through the appraising item "didik" in the clause "didik ini perempuan masuk surga dengan ridho suami". It signifies the scholar's perception that the salvation of women in the hereafter is determined by the propriety of her behavior towards her husband. The Salafi scholar affirms that woman must comply with her husband's command to acquire his acceptance.

In the third video which was taken from an Instagram account @bukanustadz.id, the scholar discusses the ways to get to know one's significant other without having to establish relationship with him or her. In the perspective of Salafi scholars, men and women are compelled to avoid contact [7]. Thus, the mingling between different gender is unacceptable in the perspective of Salafi scholars [7]. The most dominant process in the video deployed by the scholar is relational process comprising 13 clauses or $31.7 \%$. The relational clause is employed by the Salafi scholar in the video to embody certain parts of human body namely face and the back of palm to signify the appearance of the person. It can be seen in the clauses "Wajah memberikan simbol dari kepala sampai perutnya" and "Dan telapak tangan memberikan simbol dari perut sampai kemaluannya". In addition, the Salafi scholar in the video also affirms the principle of Islam by attaching the 
reliable source namely the Sharia Law through the clause "Itu hukum ya hukum syari begitu". The engagement is employed by the scholar namely Khalid Basamalah to support his claim based on the Sharia Law which he believes that Sharia Law cannot be questioned. He also endorses the voice of ulema to affirm that in Islam, relationship is extremely forbidden and there is a more proper way to determine the quality of one's significant other by means of checking their face and palm. The inclusion of other's source, such as "hukum syari" and "ulama" are aimed at supporting the Salafi scholar's claim about the ethics of determining the quality of one's significant other without having to be involved in a relationship. In addition, the scholar also deployed negative judgement of propriety to showcase that men and women must not have any relationship. It is exemplified through the clause "pacaran setahun dulu enggak perlu". Other negative judgement of propriety (is "gak perlu buka jilbab") also employed to showcase that women must not expose their adornment including hair. Salafi believes the importance of maintaining the principle of Sharia Law which is based on the Quran thus the principles in the Quran can longer be ossified and disputed in their viewpoint. The Quran predominantly in Surah Nur ayah 31 tells woman not to show her awrah to men unless he is her husband [10]. The determination to restoring the practice and teaching of Islam can be seen by the use of judgement of propriety by the scholar to disallow women to open their hijab so that their partners can see their appearance.

Another oddity is found when Muslim women are addressed first in the video as in the clause "Ada tiga hal mendasar yang ibu ibu boleh bapak bapak boleh lakukan" despite the initial part of the video talks about the procedures/mechanism of how men are able to know the quality of their significant other without having to ask their future wife to take off their hijab (the focus is on the woman's sexual body parts; the target audience is the male Muslims). In this sense, the closing part of this video demonstrates a linguistic ("patriarchal") twist, i.e. the opening part directs the audience to the sharia law that in order to know the enigmatic relation between physical quality of Muslim women (read: the one who dons hijab) with their inner quality, their focus should be on the women's face and palm (this indirectly addresses to the male audience). However, the clause "Ada tiga hal mendasar yang ibu ibu boleh bapak bapak boleh lakukan" in the body part of the preaching, at the same time, indicates that the female audiences are the main target addressers, and afterwards followed by the males.

In addition to this, this video also demonstrates how woman's sexuality should be expressed. The face and palm (especially the palm's back) are the "off-the-hijab" areas that can be displayed by Muslim women to the observant males (read also: male gaze), in this the context of seeking his future bride. Not only does this reflect the women's obedience to the sharia law, but that more importantly it also indicates that these "sexual" body parts indicate the extent by which (Muslim) males should decipher in order to identify the inner and outer qualities of Muslim women. From the video, we are informed that the women's face represents the analogues relation between physical and the inner qualities of female body (head to stomach) and soul, whilst the back of her palm reflects the analogues quality of her physical lower body (stomach to toe) in relation to her personality (read also: soul). Reading the women's palmistry is also off-limit as the males merely glance the woman's back palm and face. This information is, however, firstly addressed to female (Muslim) audiences, then males, albeit the context is for the men to decipher the hijabed Muslim's sexual mystique.

\section{Conclusion}

The three videos suggest that the use of patriarchal language of the male preachers positions women as submissive, vulnerable, and obedient vis-à-vis the domestic issue, and at the same time to how they (should) perceive (/interpet) their own body and sexuality This can be seen by how Salafi scholars linguistically framed women's servitude to their husbands. This is elemental as their submission and obedience are the requirements for them to achieve salvation and blessing. Salafi scholars also view the importance of maintaining the principle of Islam in finding partner and expressing their sexuality. These three female Muslim far-reaching issues are framed with the dominant deployment of negative judgement of propriety (social sanction: condemning) and material process. This implies how the Salafi preachers patriarchally construe (read also: 
linguistically frame) their own attitude towards the female Muslim religious praxis in relation to her body, sexuality and domestication issues.

However, from the perspective of (Indonesian Muslim) patriarchal culture, such religious language on Instagram can arguably be perceived as representing normality (the preachers patriarchally police the teachings), i.e. in order to voice the gender equity between men and women (in whatever roles they play), women are voiced to sexually fortify (read also: discipline) themselves by donning their hijab (read also: becoming docile body), so that they are not seen as evil temptress. This is crucial as albeit the women are plausibly positioned as weak, passive, submissive, subservient and subordinate to men, they are the ones who will be the saviors of their husbands, especially when their men's success both in life and hereafter depends on their blessing and prayers (indicated by the closing parts of the preaches). Though at the same time they also depend on their husbands' blessing. Mutual contingency is then inevitable, especially in these three Salafi preachers' litmus test on these "women's issues".

\section{References}

[1] E. F. Nisa, "Creative and Lucrative Da 'wa: The Visual Culture of Instagram amongst Female Muslim Youth in Indonesia," Asiascape Digit. Asia, vol. 5, pp. 68-99, 2018.

[2] Arifuddin, "Dawkah through Internet: Challenges and Opportunities for Islamic Preachers in Indonesia. Ar-Raniry," Int. J. Islam. Stud., vol. 3, no. 1, pp. 161-170, 2016.

[3] E. F. Nisa, "Social media and the birth of an Islamic social movement: ODOJ (One Day One Juz) in contemporary Indonesia," 2018, vol. 46, no. 134, pp. 24-43.

[4] \& Y. Woodward, Umar, Rohmaniyah, No Title. 2018.

[5] M. A. K. Halliday, An Intoduction To Functional Grammar. New York: Oxford University Press Inc, 2004.

[6] P. R. R. Martin, J. R., \& White, The language of evaluation: Appraisal in English. Basingstoke. England: Palgrave Macmillan UK, 2005.

[7] J. Wagenmakers, Salafi Scholarly Views on Gender-Mixing (Mixing (Ikhtilā Ikhtilāt) in Saudi Arabia. 2016.

[8] J. R. Martin and P. R. R. White, The Language of Evaluation (Appraisal in English). New York: palgrave macmillan, 2005.

[9] E. Dyer, Women and the Caliphate: Women's Rights and Restrictions in Islamist Ideology and Practice, 7th ed. London, UK: The Henry Jackson Society, 2016.

[10] A. (n. d. ). Aqeelah, "On The Awrah of A Muslim Woman To Other Muslim Women.". 